surveillance, and to the volunteers for their willing co-operation. Miss Pamela Ball provided excellent technical assistance. The unit receives a grant from the World Health Organization.

\section{REFERENCES}

Alexandrova, G. I. (1962). Acta Virologica, 6, 487.

Beare, A. S., Bynoe, M. L., and Tyrrell, D. A. J. (1968a). British Medical fournal, 4, 482.

Beare, A. S., Hobson, D., Reed, S. E., and Tyrrell, D. A. J. (1968b). Lancet, 2, 418.

Beare, A. S., et al. (1969). fournal of Hygiene, 67, 1.

Burnet, F. M., and Bull, D. R. (1943). Australian fournal of Experimental Biology and Medical Science, 21, 55.

Choppin, P. W., and Tamm, I. (1960a). Fournal of Experimental Medicine, $112,895$.

Choppin, P. W., and Tamm, I. (1960b). Fournal of Experimental Medicine, 112, 921

Choppin, P. W., Tamm, I., and Murphy, J. S. (1960). Fournal of Experimental Medicine, 112, 945.

Lief, F. S. (1964). Fournal of Immunology, 92, 286.
Maassab, H. F. (1967). Nature, 213, 612.

Maassab, H. F. (1969). Fournal of Immunology, 102, 728.

Mann, J. J., Waldman, R. H., Togo, Y., Heiner, G. G., Dawkins, A. T., and Kasel, J. A. (1968). Fournal of Immunology, 100, 726.

McDonald, J. C., Zuckerman, A. J., Beare, A. S., and Tyrrell, D. A. J. (1962). British Medical fournal, 1, 1036.

Medvedeva, T. E., Alexandrova, G. I., and Smorodintsev, A. A. (1968). fournal of Virology, 2, 456.

Slepushkin, A. N., Bobyleva, T. K., Russina, A. E., Vitkina, B. S., Ellengorn, N.' S., and Zhdanov, V. M. (1967). Bulletin of the World Health Organization, 36, 385.

Smorodintsev, A. A., Alexandrova, G. A., Chalkina, O. M., and Selivanov, A. A. (1965). In Applied Virology: 1st Annual Symposium, Boca Raton, Florida, 1964, edited by $M$. Saunders and E. H. Lenntte, p. 142. Sheboygan, Wisconsin, Ellis.

Soloviev, V. D., Neklyudova, L. I., and Orlova, N. G. (1968). Voprosy Virusologii, 13, 396. In Russian. English summary.

Soloviev, V. D., Orlova, T. G., Porubel, L. A., and Vasilieva, I. N. (1961). Voprosy Virusologii, 6, 684. English translation.

Tyrrell, D. A. J. (1963). American Review of Respiratory Diseases, 88, No. 3, part 2, p. 128.

Zhdanov, V. M. (1967). In Proceedings of First International Conference on Vaccines against Virel and Rickettsial Diseases of Man, Washington 1966, p. 9. Washington, Pan American Health Organization.

\title{
Postural Influence on Maternal Capillary Oxygen and Carbon Dioxide Tension
}

\author{
C. K. ANG,*; T. H. TAN,*; W. A. W. WALTERS, † M.B., M.R.C.o.G., PH.D. ; C. WOOD, $\ddagger$ M.B., F.R.c.s., F.R.C.o.g.
}

\begin{abstract}
Summary : The effect of posture on maternal capillary $\checkmark$ blood $\mathrm{Po}_{2}$ and $\mathrm{Pco}_{2}$ was studied in pregnant and non-pregnant women. There was a significant decrease of $\mathrm{Po}_{2}$ (mean $13.0 \mathrm{~mm}$. $\mathrm{Hg}$ ) and significant decrease of $\mathrm{Pco}_{2}$ (mean $2.4 \mathrm{~mm} . \mathrm{Hg}$ ) when pregnant women sat up, but these changes did not occur in the non-pregnant. These findings may be relevant to debate on the optimum posture for labour.
\end{abstract}

\section{Introduction}

In the sixteenth century patients were delivered in an obstetric chair (Cutter and Viets, 1964). Today the African Bantu still gives birth in the sitting position, and this has led to the suggestion that this position be adopted for childbirth. Obviously, when bearing down, gravity would be an additional force when the patient was in the erect or sitting position. The major disadvantage of an upright posture during delivery would be the difficulty the accoucheur would have in gaining access to the site of delivery. The effect of posture on maternal blood oxygen levels has not been studied, though the lowest mean arterial blood $\mathrm{PO}_{2}$ reported in pregnant patients was in subjects studied in the dorsal position, while the highest mean arterial blood $\mathrm{Po}_{2}$ was in patients studied in the sitting position (Rooth and Sjöstedt, 1962 ; Stenger et al., 1964). As asphyxia is a common cause of stillbirth any factor influencing maternal oxygenation deserves investigation, and the present experiments were designed to study the effect of posture on maternal blood oxygen levels.

* Fifth-year Monash University Medical Student.

† Senior Lecturer.

$¥$ Professor.

Department of Obstetrics and Gynaecology, Monash University, Queen Victoria Hospital, Melbourne, Victoria, Australia.

\section{Material and Methods}

Ten patients between the 35th and 40th weeks of their pregnancy were studied, four of them being primigravidae. Their ages ranged from 17 to 35 years. The control group consisted of 10 non-pregnant women of similar age and parity. None of the patients were obese or were taking drugs, and none had evidence of cardiovascular or pulmonary disease. The experimental procedure was explained to each patient, who had previously volunteered for the study.

The basis of the experimental procedure was a series of observations made on each patient in two different positions: supine with one pillow under the head and two pillows under the calf, and sitting with the body slightly forward of the vertical position. After the patient had been in the supine position for 20 minutes the pulse and blood pressure were recorded and a blood sample was taken; this procedure was repeated five minutes later. The patient then changed her position to the erect one, and after 10 minutes two more sets of measurements (pulse, blood pressure, and blood sample) were taken with a five-minute interval between them.

The blood pressure was recorded with a sphygmomanometer, and care was taken to maintain the arm cuff at the level of the heart during all recordings. Each blood pressure measurement represented the mean of three readings taken at one-minute intervals.

The blood sample was collected from the ear lobe after it was made hyperaemic with tetrahydrofurfuryl nicotinic acid ester paste. Capillary blood $\mathrm{Po}_{2}$ and $\mathrm{PcO}_{2}$ measured from samples taken from the ear lobe have been shown to compare favourably with arterial blood oxygen and carbon dioxide levels (Siggaard-Andersen, 1967; Koch, 1968). Comparison of capillary and arterial blood in our laboratory has produced results similar to those of Koch, the mean arterial/capillary 
differences for $\mathrm{PO}_{2}$ being $+4.5 \%$ and for $\mathrm{PCO}_{2}+4.3 \%$ (Walker and Lumley, 1969). In addition the precision of arterial and capillary measurements carried out under the same conditions was similar. The $\mathrm{Po}_{2}$ and $\mathrm{PCO}_{2}$ electrodes of an Instrumentation Laboratories ultramicroelectrode assembly were calibrated with analysed gas mixtures.

The $95 \%$ confidence limits for duplicate measurements were $\pm 7.6 \mathrm{~mm}$. $\mathrm{Hg}$ for $\mathrm{PO}_{2}$ and $\pm 3.9 \mathrm{~mm}$. $\mathrm{Hg}$ for $\mathrm{PCO}_{2}$. The confidence limits were calculated from the differences between duplicate measurements on blood collected in different tubes from the same cut, the data from all cases (Youden, 1951) being used. The confidence limits of blood $\mathrm{PO}_{2}$ and $\mathrm{PCO}_{2}$ measurement will be affected both by the speed of blood collection and by the mixing of the blood after collection, as arterial blood $\mathrm{PCO}_{2}$ and $\mathrm{PO}_{2}$ levels have oscillatory patterns which are dependent on physiological oscillatory changes in respiration (Lenfant, 1967). Capillary blood is not collected as rapidly as arterial blood, and this may influence the confidence limits of the measurements. The difference between our duplicates is quite consistent with the changes that Lenfant (1967) demonstrated in arterial blood over a short period of time. The blood samples were collected in nylon tubing and coded in such a way that the investigator carrying out the measurement did not know whether the blood was collected from the patient in the supine or the erect position.

\section{Results}

When the pregnant patients changed from the supine to the sitting position the mean capillary blood $\mathrm{Po}_{2}$ increased by $13 \mathrm{~mm} . \mathrm{Hg}$, this change being statistically significant, $\mathrm{P}<0.01$ (Table I). The increase of $\mathrm{PO}_{2}$ was associated with a mean

\begin{tabular}{|c|c|c|c|c|c|c|}
\hline \multirow{2}{*}{$\begin{array}{c}\text { Pregnant } \\
\text { women }\end{array}$} & \multicolumn{3}{|c|}{$\mathrm{Po}_{2}(\mathrm{~mm} \mathrm{Hg})$} & \multicolumn{3}{|c|}{$\mathrm{PCO}_{2}(\mathrm{~mm} \mathrm{Hg})$} \\
\hline & Supine & Sitting & ${ }_{\text {Supine })}^{(\text {Sitting- }}$ & Supine & Sitting & $\Delta \underset{\text { Supine })}{(\text { Sitting }}$ \\
\hline \multirow[t]{2}{*}{$\begin{array}{c}1 \\
2 \\
3 \\
4 \\
5 \\
6 \\
7 \\
8 \\
9 \\
10 \\
\text { Mean } \\
\text { Standard } \\
\text { deviation } \\
\text { P }\end{array}$} & $\begin{array}{c}99 \\
95 \\
101 \\
92 \\
70 \\
89 \\
88 \\
75 \\
78 \\
67 \\
85^{*} \\
\pm 12\end{array}$ & $\begin{array}{c}117 \\
110 \\
105 \\
103 \\
92 \\
103 \\
99 \\
97 \\
80 \\
78 \\
98^{*} \\
\pm 12\end{array}$ & $\begin{array}{r}+18 \\
+15 \\
+4 \\
+11 \\
+22 \\
+14 \\
+11 \\
+22 \\
+2 \\
+11 \\
+13 \\
\pm 7\end{array}$ & $\begin{array}{l}29 \\
32 \\
34 \\
28 \\
32 \\
32 \\
34 \\
32 \\
36 \\
32 \\
32 \dagger \\
\pm 2\end{array}$ & $\begin{array}{l}23 \\
31 \\
33 \\
26 \\
30 \\
31 \\
29 \\
30 \\
34 \\
30 \\
30 \dagger \\
\pm 3\end{array}$ & $\begin{array}{l}-6 \\
-1 \\
-1 \\
-2 \\
-2 \\
-1 \\
-5 \\
-2 \\
-2 \\
-2 \\
-2 \\
\pm 1\end{array}$ \\
\hline & \multicolumn{3}{|c|}{$*<0.01(\mathrm{~S})$} & \multicolumn{3}{|c|}{$t<0.01(S)$} \\
\hline $\begin{array}{r}1 \\
2 \\
3 \\
4 \\
5 \\
6 \\
7 \\
8 \\
9 \\
10\end{array}$ & $\begin{array}{r}80 \\
107 \\
89 \\
83 \\
81 \\
92 \\
80 \\
84 \\
78 \\
75\end{array}$ & $\begin{array}{l}82 \\
92 \\
95 \\
79 \\
81 \\
90 \\
80 \\
91 \\
77 \\
78\end{array}$ & $\begin{array}{c}+2 \\
-15 \\
+6 \\
-4 \\
0 \\
-2 \\
0 \\
+7 \\
-1 \\
+3\end{array}$ & $\begin{array}{l}34 \\
33 \\
35 \\
35 \\
37 \\
33 \\
32 \\
37 \\
38 \\
33\end{array}$ & $\begin{array}{l}31 \\
35 \\
32 \\
35 \\
36 \\
34 \\
32 \\
36 \\
40 \\
33\end{array}$ & $\begin{array}{r}-3 \\
+2 \\
-3 \\
0 \\
-1 \\
+1 \\
0 \\
-1 \\
+2 \\
0\end{array}$ \\
\hline \multirow[t]{2}{*}{$\begin{array}{l}\text { Mean } \\
\text { Stan Jard } \\
\text { deviation }\end{array}$} & $\begin{array}{l}85 \ddagger \\
\pm 9\end{array}$ & $\begin{array}{l}85 \ddagger \\
\pm 7\end{array}$ & $\begin{array}{l}-2 \\
\pm 6\end{array}$ & $\begin{array}{l}355 \\
\pm 2\end{array}$ & $\begin{array}{l}345 \\
\pm 3\end{array}$ & $\begin{array}{l}-1 \\
\pm 1\end{array}$ \\
\hline & \multicolumn{3}{|c|}{$\ddagger>0.5$ (N.S.) } & \multicolumn{3}{|c|}{$\varsigma^{\prime}>0.5$ (N.S.) } \\
\hline
\end{tabular}

decrease of $2.4 \mathrm{~mm}$. $\mathrm{Hg}$ in blood $\mathrm{PCO}_{2}$, this change also being significant, $\mathrm{P}<0.01$. When the non-pregnant patients sat up no significant alteration of blood $\mathrm{PO}_{2}$ or $\mathrm{PCO}_{2}$ was found. Comparison between the pregnant and non-pregnant groups showed that the alteration in oxygen level with change of posture was significantly different between the two groups, $\mathrm{P}<0.01$, but the alteration in carbon dioxide with alteration of posture was not, $\mathbf{P}>0.2$. The variation in the degree of change of blood gases with alteration of posture in individual patients could not be related to the subject's age, weight, parity, or smoking habits.
In pregnant patients the pulse rate and blood pressure did not significantly alter with change of posture; in the nonpregnant patients there was a statistically significant increase of diastolic pressure when they assumed the sitting position; the importance of this finding, however, is uncertain, as the mean change was only $3.4 \mathrm{~mm}$. $\mathrm{Hg}$ (Table II).

\begin{tabular}{|c|c|c|c|c|c|c|c|}
\hline & \multicolumn{4}{|c|}{ Blood pressure $(\mathrm{mm} . \mathrm{Hg})$} & \multicolumn{3}{|c|}{ Pulse Rate } \\
\hline & $\mid \begin{array}{l}\text { Systolic (S) } \\
\text { Diastolic (D) }\end{array}$ & Supine & Sitting & $\left|\begin{array}{c}\Delta \text { Supine }) \\
\text { (Sitting- }\end{array}\right|$ & Supine & Sitting & $\Delta$ Supine) \\
\hline & \multicolumn{7}{|c|}{10 Pregnant Women } \\
\hline Mean & D & $\begin{array}{l}125 * \\
82 t\end{array}$ & $85 t$ & $\begin{array}{l}-3 \\
+3\end{array}$ & $76^{*}$ & $70^{*}$ & -1 \\
\hline $\begin{array}{l}\text { Standard } \\
\text { deviation }\end{array}$ & S & $\begin{array}{r} \pm 12 \\
\pm 9\end{array}$ & $\begin{array}{l} \pm 12 \\
\pm 11\end{array}$ & $\begin{array}{l} \pm 5 \\
\pm 5\end{array}$ & \pm 7 & \pm 7 & \pm 6 \\
\hline $\mathbf{P}$ & S & \multirow{2}{*}{\multicolumn{3}{|c|}{$\begin{array}{l}*>0.05 \text { (N.S.) } \\
t>0.05 \text { (N.S.) }\end{array}$}} & \multicolumn{3}{|c|}{$*>0.50$ (N.S.) } \\
\hline & & & & zant Women & $\mathrm{XC}$ & $72^{*}$ & $+1 \cdot 1$ \\
\hline Mean & D & $\begin{array}{r}115 F \\
719\end{array}$ & 749 & +3.4 & & $12^{\circ}$ & +1.1 \\
\hline $\begin{array}{l}\text { Standard } \\
\text { deviation }\end{array}$ & S & $\begin{array}{l} \pm 7 \\
\pm 6\end{array}$ & $\begin{array}{l} \pm 7 \\
\pm 8\end{array}$ & $\pm \frac{ \pm 6}{4}$ & \pm 9 & \pm 11 & \pm 2 \\
\hline $\mathbf{P}$ & S & & $\begin{array}{l}\ddagger>0.1(1 \\
\Phi<0.02\end{array}$ & $\begin{array}{l}\text { N.S. } \\
(\mathbf{S})\end{array}$ & & 0.50 & N.S.) \\
\hline
\end{tabular}

\section{Discussion}

Pregnant subjects showed a marked increase of capillary blood $\mathrm{PO}_{2}$ and a small but significant decrease of capillary blood $\mathrm{PCO}_{2}$ when altering their position from supine to sitting. This change is unlikely to be temporary, as blood gas measurements were shown to be steady in each position. The effect of posture on maternal $\mathrm{PO}_{2}$ may be one factor contributing to the variation in values of maternal arterial oxygen tension reported in other studies: $91 \mathrm{~mm}$. $\mathrm{Hg}$ (Wulf, 1958), $69 \mathrm{~mm}$. Hg (Vasicka et al., 1960), $80 \mathrm{~mm}$. Hg (Stenger et al., 1964). and $97 \mathrm{~mm}$. Hg (Rooth and Sjöstedt, 1962). While the effects of anaesthesia may also have contributed to the variation in the previously reported levels of maternal arterial $\mathrm{Po}_{2}$ (Metcalfe et al., 1967), the change from a mean capillary $\mathrm{Po}_{2}$ of $85 \mathrm{~mm}$. $\mathrm{Hg}$ in the dorsal position to $98 \mathrm{~mm}$. $\mathrm{Hg}$ in the sitting position in the present study emphasizes the need to consider the influence of posture in studies dependent on measurement of maternal blood $\mathrm{Po}_{2}$. That maternal capillary blood $\mathrm{Po}_{2}$ in favourable conditions is usually greater than $90 \mathrm{~mm}$. $\mathrm{Hg}$ has been repeatedly documented in our own previous studies with the "arterialized capillary" method: $98 \mathrm{~mm}$. Hg (Lumley et al., 1969b), $94 \mathrm{~mm}$. Hg (Lumley et al., 1969a), $101 \mathrm{~mm}$. Hg (Krins et al., 1969), $90 \mathrm{~mm}$. Hg (Newman et al., 1967). Because of the concordance between arterial and capillary blood $\mathrm{PO}_{2}$ in our laboratory and in other studies (Siggaard-Andersen, 1967) it is probable that in favourable circumstances maternal arterial $\mathrm{Po}_{2}$ is above $90 \mathrm{~mm}$. $\mathrm{Hg}$. The mean value for maternal capillary $\mathrm{PCO}_{2}, 32 \mathrm{~mm}$. $\mathrm{Hg}$, is consistent with the known occurrence of hyperventilation in pregnancy (MacRae and Palavradji, 1967) and our own previous measurements of maternal capillary $\mathrm{PCO}_{2}$ during pregnancy and early labour: $28 \mathrm{~mm}$. $\mathrm{Hg}$ (Lumley et al., 1969a), $28 \mathrm{~mm}$. Hg (Newman et al., 1967). The value of the control group was limited, as the changes in the pregnant patients were clear-cut and the measurements concordant in the two separate blood collections made in each position. Furthermore, the non-pregnant patients forming the control group were also hyperventilating to some extent, as their mean $\mathrm{PCO}_{2}$ was $35 \mathrm{~mm}$. Hg. Nevertheless, the absence of significant changes in blood gases in the non-pregnant patients when they changed position is also consistent with the findings of Riley et al. (1959).

The mechanisms determining the increase of $\mathrm{Po}_{2}$ and decrease of $\mathrm{PCO}_{2}$ in the pregnant woman assuming the sitting position are not known, as a number of other criteria would require measurement in order to elucidate this. It would seem that the effect of posture in the non-pregnant patient is not neces- 
sarily relevant in seeking an explanation of the changes in the pregnant patient, as a number of changes in cardiovascular or respiratory function occur in pregnancy which may modify postural responses. Hyperventilation is normal in pregnancy (Reid et al., 1967), the diaphragm is raised (McGinty, 1938), pulmonary diffusing capacity may be lower (Bedell and Adams, 1962), and expiratory reserve volume, residual volume, and mean functional residual capacity are all reduced in the third trimester (Gaensler, 1965). The reduction of expiratory reserve volume in pregnancy may be related to the susceptibility of pregnant patients to a postural influence on $\mathrm{Po}_{2}$, as it has been shown that ventilation perfusion abnormalities occur in obese non-pregnant subjects and that this bears a relation to the expiratory reserve volume and can reduce arterial $\mathrm{Po}_{2}$ during resting tidal ventilation (Holley et al., 1967). Ventilation in the lower lung zones may be reduced in the pregnant patient lying in the supine position, as the fetus is closer to the diaphragm than when the patient is sitting or standing. This, together with the reduced expiratory reserve volume of the pregnant patient, may produce ventilation perfusion inequality in the lower lung zones and account for the lower $\mathrm{Po}_{2}$ in the supine position.

Cardiac output is increased in pregnancy (Adams, 1954 ; Walters et al., 1966 ; Lees et al., 1967), but the effects of posture on cardiac output in pregnancy are not clear. Lees et al. (1967) have shown that cardiac output at the end of pregnancy increases if the patient turns from the supine to the right lateral position, so that it might be thought possible for a similar change to occur if a pregnant patient changes from the supine to the sitting position. Quilligan and Tyler (1959), however, found insignificant changes in cardiac output when pregnant patients moved from the lateral to the supine position. Even more relevant to the present study is the work of Pyörälä (1966), who found no change in cardiac output or pulse rate when late pregnant patients were tilted from the supine to a $60^{\circ}$ upright position. Thus evidence is not yet available to determine whether the effect of posture on maternal capillary $\mathrm{PO}_{2}$ is dependent on alteration of cardiovascular mechanisms. Again it is possible that aortocaval compression, which is sometimes present in pregnant patients lying in the supine position (Bieniarz et al., 1969), may be reduced when the patient sits up, but further studies would be necessary to determine whether such a change could increase capillary blood $\mathrm{Po}_{2}$.

As maternal capillary $\mathrm{Po}_{2}$ is higher in the sitting position the role of bed rest in the lying position for obstetric complications requires careful re-evaluation. It is known that maternal $\mathrm{PO}_{2}$ levels may influence fetal scalp blood or tissue Po, levels (Newman et al., 1967 ; Walker et al., 1968), so that any factor decreasing maternal $\mathrm{Po}_{2}$ should, if possible, be avoided. The left lateral position may be as advantageous as the sitting position in maintaining a high maternal $\mathrm{PO}_{2}$ level, but, even if this is found to be so, most patients resting in bed assume the supine position. The lower $\mathrm{Po}_{2}$ level in the supine position cannot be considered important in a normal situation, but if complications are already present which prejudice fetal oxygenation-for example, shock, blood loss, pre-eclampsia, placental insufficiency-the position the patient assumes may be critical. The importance of the present findings in labour is difficult to estimate, as further cardiovascular or respiratory changes may occur which would modify the response to alteration of posture. If the present findings applied to labour then there would be a physiological reason to return to the use of an obstetric chair. While this may pose difficulty for the accoucheur, it is also a more natural position in which to bear down, aided by gravity.

We wish to thank the nursing staff of the Queen Victoria Hospital and the technical staff of the Department of Obstetrics and Gynaecology for their help in carrying out this study.

\section{REFERENCES}

Adams, J. Q. (1954). American fournal of Obstetrics and Gynecology, 67,741 .

Bedell, G. N., and Adams, R. W. (1962). Fournal of Clinical Investigation, 41, 1908.

Bieniarz, J., Yoshida, T., Romero-Salanias, C., Curuchet, E., CaldeyroBarcia, R., and Crottogni, J. J. (1969). American fournal of Obstetrics and Gynecology, 103, 19.

Cutter, I. S., and Viets, H. R. (1964). A Short History of Midwifery. Philadelphia, Saunders.

Gaensler, E. A. (1965). In Handbook of Physiology : Section 3, Respiration, Vol. 2 , edited by W. O. Fenn and H. Rahn, p. 1623. Washington, American Physiological Society.

Holley, H. S., Milic-Emili, J., Becklake, M. R., and Bates, D. V. (1967). fournal of Clinical Investigation, 46, 475.

Koch, G. (1968). Scandinavian Fournal of Clinical and Laboratory Investigation, 21, 10

Krins, A. J., Mitchell, W. R., and Wood, C. (1969). Fournal of Obstetrics and Gynaecology of the British Commonwealth, 76, 359.

Lees, M. M., Scott, D. B., Kerr, M. G., and Taylor, S. H. (1967). Clinical Science, 32, 453.

Lenfant, C. (1967). Journal of Applied Physiology, 22, 675.

Lumley, J., Hammond, J., and Wood, C. (1969a). Fournal of Obstetrics and Gynaecology of the British Commonwealth, 76, 512.

Lumley, J., Renou, P., Newman, W., and Wood, C. (1969b). American fournal of Obstetrics and Gynecology, 103, 847.

McGinty, A. P. (1938). American fournal of Obstetrics and Gynecology, 35, 237.

MacRae, D. J., and Palavradii, D. (1967). Fournal of Obstetrics and Gynaecology of the British Commonwealth, 74, 11.

Metcalfe, J., Bartels, H., and Moll, W. (1967). Physiological Review, 47, 782 .

Newman, W., McKinnon, L., Phillips, L., Paterson, P., and Wood, C. (1967). American fournal of Obstetrics and Gynecology, 99, 61.

Pyörälä, T. (1966). Acta Obstetrica et Gynecologica Scandinavica, 45, Suppl. No. 5.

Quilligan, E. J., and Tyler, C. (1959). American fournal of Obstetrics and Gynaecology, 78, 465.

Reid, D. H. S., Tunstall, M. E., and Mitchell, R. G. (1967). Lancet, 1,532 .

Riley, R. L., et al. (1959). Journal of Applied Physiology, 14, 339.

Rooth, G., and Sjöstedt, S. (1962). Archives of Diseases in Childhood, 37,366 .

Siggaard-Andersen, O. (1968). Scandinavian fournal of Clinical and Laboratory Investigation, 21, 289.

Stenger, V., Eitzman, D., Anderson, T., De Padua, C., Gessner, I., and Prystowsky, H. (1964). American fournal of Obstetrics and Gynecology, 88, 45 .

Vasicka, A., Quilligan, E. J., Aznar, R., Lipsitz, P. J., and Bloor, B. M. (1960). American fournal of Obstetrics and Gynecology, 79, 1041.

Walker, A., and Lumley, J. (1969). To be published.

Walker, A. Phillips, L., Powe, L., and Wood, C. (1968). American fournal of Obstetrics and Gynecology, 100, 63.

Walters, W. A. W., MacGregor, W. G., and Hills, M. (1966). Clinical Science, 30, 1 .

Wulf, H. (1958). Klinische Wochenschrift, 36, 234.

Youden, W. J. (1951). Statistical Methods for Chemists, p. 16. New York, Wiley. 